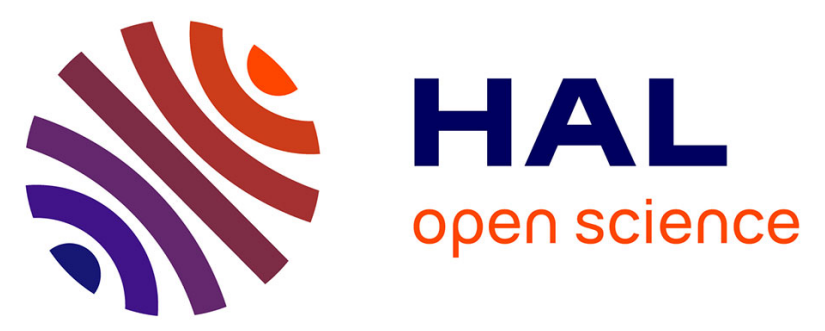

\title{
Onset of gonadotropic hormone accumulation in the immature trout pituitary gland in response to estrogen or aromatizable androgen steroid hormones
}

\author{
L.W. Crim, R.E. Peter, Roland Billard
}

\section{- To cite this version:}

L.W. Crim, R.E. Peter, Roland Billard. Onset of gonadotropic hormone accumulation in the immature trout pituitary gland in response to estrogen or aromatizable androgen steroid hormones. General and Comparative Endocrinology, 1981, 44 (3), pp.374-381. 10.1016/0016-6480(81)90015-0 . hal01604337

\section{HAL Id: hal-01604337 \\ https://hal.science/hal-01604337}

Submitted on 2 Jun 2020

HAL is a multi-disciplinary open access archive for the deposit and dissemination of scientific research documents, whether they are published or not. The documents may come from teaching and research institutions in France or abroad, or from public or private research centers.
L'archive ouverte pluridisciplinaire HAL, est destinée au dépôt et à la diffusion de documents scientifiques de niveau recherche, publiés ou non, émanant des établissements d'enseignement et de recherche français ou étrangers, des laboratoires publics ou privés.

\section{다(1)(2)}

Distributed under a Creative Commons Attribution - ShareAlikel 4.0 International 


\title{
Onset of Gonadotropic Hormone Accumulation in the Immature Trout Pituitary Gland in Response to Estrogen or Aromatizable Androgen Steroid Hormones ${ }^{1}$
}

\author{
L. W. Crim, ${ }^{*}$ R. E. Peter, $\dagger$ ANd R. Billard $\ddagger$ \\ *Marine Sciences Research Laboratory, Memorial University of Newfoundland, St. John's, Newfoundland \\ AlC 5S7 Canada; †Department of Zoology, University of Alberta, Edmonton, Alberta T6G 2E9 Canada; \\ and $\ddagger$ Institut National de la Recherche Agronomique, Laboratoire de Physiologie des Poissons, \\ 7835 Jouy en Josas, France
}

Accepted November 20, 1980

\begin{abstract}
A study was conducted to determine the specificity of the steroids able to cause a stimulation of pituitary gonadotropic hormone $(\mathrm{GtH})$ levels in sexually immature rainbow trout. Low pituitary GtH levels characteristic of juvenile trout were rapidly elevated following treatment with estrogen and aromatizable androgenic steroid hormones, but nonaromatizable androgens and progestogenic steroids were ineffective. An aromatase inhibitor, 1,4,6androstatrien-3,17-dione, significantly reduced the pituitary GtH increase in response to treatment with testosterone. A central effect of steroid hormones on pituitary $\mathrm{GtH}$ was confirmed by the fact that pituitary steroid implants did not increase liver weight as observed after perivisceral hormone treatment. The possible participation of sex steroids in a mechanism of initiation of gonad recrudescence or onset of pubertal gonadal development in salmonids is discussed.
\end{abstract}

Annual reproductive cycles of teleost fishes are supported by the endocrine activities of the brain-pituitary-gonad axis. Plasma profiles of gonadotropin $(\mathrm{GtH})$ and steroid hormones associated with seasonal development of the trout gonad (Billard $e t$ al., 1978; Billard and Breton, 1979) show that peak hormone levels are achieved at the time of full reproductive development and spawning. Plasma GtH levels increase during sexual development of the precocious Atlantic salmon parr (Crim and Evans, 1978) and this study also showed that pituitary GtH levels vary dramatically throughout the seasonal sexual cycle. Seasonal patterns of cytological activity reflecting growth and development of gonadotrophs in the pituitary of trout and salmon have been previously described (Olivereau, 1976; Ekengren et al., 1978; Peute et al., 1978).

Some previous studies indicate that GtH secretion is under negative steroid feedback

\footnotetext{
${ }^{1}$ M.S.R.L. contribution number 407 .
}

regulation in teleosts. Estrogen and androgen treatment suppresses the activity of pituitary gonadotrophs in the Indian catfish (Sundararaj and Goswami, 1968); hypothalamic neurosecretory activity also declines (Viswanathan and Sundararaj, 1974). GtH increased in the plasma of mature female goldfish quickly following hypothalamic implants of an estrogen inhibitor (Billard and Peter, 1977). Castration of rainbow trout induces a rise in plasma GtH which is diminished following treatment with androgen (Billard et al., 1977; Billard, 1978), providing additional evidence for a negative feedback effect by steroids in teleosts.

Recent work indicates that a positive feedback effect of sex steroids plays an important role in regulation of $\mathrm{GtH}$ production and/or secretion in some teleosts. Brain implants of testosterone increased pituitary GtH in Atlantic salmon parr (Crim and Peter, 1978) and this pituitary GtH response was also demonstrated following systemic testosterone treatment of immature rain- 
bow trout (Crim and Evans, 1979). Olivereau and Olivereau $(1979 \mathrm{a}, \mathrm{b})$ found that treatment of immature silver eels with estrogen caused a striking development of pituitary GtH cells, suggesting that the positive feedback action to induce GtH production or appearance in the pituitary gland of immature fish can be by either androgens or estrogens. The present studies were designed to investigate the specificity of the steroids involved in this response in immature rainbow trout.

\section{MATERIALS AND METHODS}

Experiment I. In October 1977, sexually immature yearling rainbow trout were selected from two groups of laboratory stock (Jouy-en-Josas, France) having average body weights of 183 (SD 25) and $152 \mathrm{~g}$ (SD 15), respectively. Groups of 15 of the larger fish were treated with a steroid hormone (testosterone, $\mathrm{T}$; estradiol-17 $\beta, \mathrm{E}_{2}$; cortisol) dissolved initially with absolute ethanol and then into cocoa butter $(1: 40, v / v)$. The steroids in cocoa butter were injected into the perivisceral (PV) cavity $(0.2 \mathrm{ml}$ molten cocoa butter containing $21 \mu \mathrm{g}$ steroid). The smaller fish were treated with a small cocoa butter implant (Billard and Peter, 1977) containing about $4 \mu \mathrm{g}$ steroid. The steroid pellets were implanted directly into the pituitary gland using stereotoxic procedures (R. Peter and R. Billard, unpublished). Blood samples were collected at 3 and 7 days after steroid treatment. At the time of autopsy on Day 7 weights for body, viscera, and liver were obtained. The pituitary gland was quickly removed and frozen onto small aluminum pans over liquid nitrogen. Pituitaries were lyophilized to dryness, weighed and

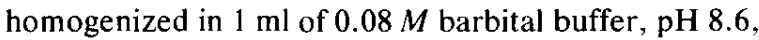
and stored frozen in preparation for radioimmunoassay of trout gonadotropin $(\mathrm{GtH})$ according to Billard et al. (1977).

Experiment 2. In July 1979 sexually immature rainbow trout weighing from 38 to $53 \mathrm{~g}$ were selected (St. John's, Canada). Groups of six fish received a PV injection of $0.2 \mathrm{ml}$ molten cocoa butter containing $20 \mu \mathrm{g}$ of a steroid hormone ( $\mathrm{T}$, testosterone propionate, $17 \alpha$-methyltestosterone, androstenedione, $5 \alpha$-dihydrotestosterone, 11-ketotestosterone, 11 $\beta$-hydroxytestosterone, $\mathrm{E}_{2}$, estrone, estriol, $17 \alpha$-hydroxyprogesterone, $17 \alpha$-hydroxy-20 $\beta$-dihydroprogesterone), or $20 \mu \mathrm{g}$ cholesterol, or $20 \mu \mathrm{g}$ of the aromatase inhibitor 1,4,6-androstatrien-3,17-dione (ATD, dissolved initially in a small volume of acetone), $100 \mu \mathrm{g}$ ATD, $20 \mu \mathrm{g}$ ATD plus $20 \mu \mathrm{g} \mathrm{T}$, and $100 \mu \mathrm{g}$ ATD plus 20 $\mu \mathrm{g} T$. Seven days following the steroid injection into the body cavity the fish were autopsied and pituitaries were collected and handled in preparation for salmon $\mathrm{GtH}$ radioimmunoassay (Crim et al., 1975) as described above.

Experiment 3. An experiment was conducted in January 1980 on immature rainbow trout weighing from 44 to $72 \mathrm{~g}$ (St. John's, Canada). In this experiment androgenic steroids ( $\mathrm{T}, 5 \alpha$-dihydrotestosterone, 11-ketotestosterone, 11 $\beta$-hydroxytestosterone) were dissolved in $10 \%$ benzyl benzoate in peanut oil (PO). On alternate days (total of three injections) trout received a PV injection of $0.2 \mathrm{ml} \mathrm{PO}$-vehicle or POvehicle containing $20 \mu \mathrm{g}$ of steroid hormone. After 7 days the autopsies were performed and pituitaries were collected and prepared for GtH determination by RIA.

Statistics. The data are expressed as mean \pm standard error. Analysis of variance was done by the Kruskal-Wallis test and the difference between groups was determined by the Mann-Whitney $U$ test (Sokal and Rolff, 1969). In cases in which there was homogeneity of variance between groups within an experiment, the significance between groups was determined by Student's $t$ test.

\section{RESULTS}

The results of the first experiment, in which juvenile rainbow trout received a pituitary cocoa butter implant or a PV injection of cocoa butter with or without $T$, $E_{2}$, or cortisol, are reported in Table 1 . There were no apparent differences in the pituitary GtH levels between male and female trout within the various experimental groups (data not shown). The results shown in Table 1 indicate that the pituitaries of sham (PV) cocoa-butter-treated fish contain GtH in very low amounts. Systemic cortisol treatment (PV injection) did not change the pituitary GtH level, but both $\mathrm{T}$ and $\mathrm{E}_{2}$ were effective via the systemic route. Direct pituitary treatment with $\mathrm{T}$ or $\mathrm{E}_{2}$ also significantly increased pituitary GtH in the immature trout compared with sham cocoa-butter-implanted fish. A small increase in pituitary GtH concentration was observed when cortisol was implanted directly into the pituitary gland. Attempts to measure plasma GtH of the immature rainbow trout indicated that the hormone level was extremely low, and alterations in the low basal plasma GtH level were not observed following steroid treatment of the immature rainbow trout (data not shown). The data in Table 2 
TABLE 1

Influence of Perivisceral (PV) Injection or Pituitary

(Pit) Implantation of Steroids on Pituitary

Concentration of Gonadotropin (GTH) in JuVEnile Rainbow Trout

\begin{tabular}{|c|c|c|c|c|c|}
\hline \multirow{2}{*}{$\frac{\text { Treatment }}{\text { Cocoa butter }}$} & \multirow{2}{*}{$\frac{\begin{array}{c}\text { Site of } \\
\text { implant }\end{array}}{\text { PV }}$} & \multirow{2}{*}{$\frac{N}{15}$} & \multicolumn{2}{|c|}{$\begin{array}{c}\text { Pituitary GtH } \\
\text { (ng/mg) }\end{array}$} & \multirow{2}{*}{$\frac{\text { Significance }}{-}$} \\
\hline & & & $16.4 \pm$ & 3.8 & \\
\hline Cortisol & PV & 15 & $11.1 \pm$ & 1.0 & NS \\
\hline Estradiol & PV & 15 & $389 \pm$ & 36 & $P<0.001^{\prime \prime}$ \\
\hline Testosterone & PV & 14 & $239 \pm$ & 30 & $P<0.001^{\prime \prime}$ \\
\hline Cocoa butter & Pit & 14 & $73.5 \pm$ & 45.0 & - \\
\hline Cortisol & Pit & 16 & $185 \pm$ & 53 & $P<0.01^{b}$ \\
\hline Estradiol & Pit & 14 & 420 & 62 & $P<0.001^{b}$ \\
\hline Testosterone & Pit & 16 & 1984 & 374 & $P<0.001^{\prime \prime}$ \\
\hline
\end{tabular}

"Significance compared to cocoa butter PV by $U$ test.

"Significance compared to cocoa butter Pit by $U$ test.

show the results of treating fish with steroids in cocoa butter on the relative liver weight (HSI). There was an apparent difference between control HSI of fish receiving direct pituitary treatment or perivisceral injections of cocoa butter. This could be due to differences in body weight between these groups of fish. In the fish receiving direct pituitary steroid implants, there was no change in the HSI effected by the various steroids tested. However, systemic $E_{2}$ treatment significantly increased HSI in both male and female trout. Perivisceral treatment with cortisol and $\mathrm{T}$ was effective only in females.

The results of experiment 1 indicated that both androgenic and estrogenic steroid hormones stimulate the pituitary GtH level of sexually immature trout. In experiment 2 , a variety of steroids were injected PV in molten cocoa butter to test their influence on the pituitary GtH response (Table 3). T, derivatives of $\mathrm{T}$ (methyl and propionic acid substitutions), and androstenedione (a precursor of testosterone) all produced marked increases in trout pituitary GtH. However, dihydrotestosterone and the teleost androgens, 11-ketotestosterone, and 11 $\beta$-hydroxytestosterone, were completely ineffective. Of the estrogenic steroid hormones tested, all significantly increased pituitary GtH levels although $\mathrm{E}_{2}$ was more effective than estrone $(P<0.001)$ and estriol $(P<0.001)$. Two sex steroid progestines,

TABLE 2

Influence of Perivisceral Injection (Systemic) or Pituitary Implantation of Steroids on THE HEPATOSOMATIC INDEX (HSI) OF IMMATURE RAINBOW TROUT

\begin{tabular}{|c|c|c|c|c|}
\hline \multirow[b]{2}{*}{ Treatment } & \multicolumn{2}{|c|}{ Systemic treatment (HSI- $(\%))^{\prime \prime}$} & \multicolumn{2}{|c|}{ Pituitary treatment (HSI- $(\%))^{\prime \prime}$} \\
\hline & $\partial$ & $q$ & $\sigma$ & $q$ \\
\hline Cocoa butter & $1.09 \pm 0.06(8)$ & $0.95 \pm 0.06(7)$ & $1.22 \pm 0.04(5)$ & $1.30 \pm 0.16(9)$ \\
\hline Cortisol & $1.05 \pm 0.04(5)$ & $1.24 \pm 0.05(10)^{* * *}$ & $1.15 \pm 0.05(6)$ & $1.18 \pm 0.04(10)$ \\
\hline Estradiol & $1.35 \pm 0.07(10)^{* *}$ & $1.33 \pm 0.08(5)^{* * *}$ & $1.37 \pm 0.09(7)$ & $1.35 \pm 0.11(6)$ \\
\hline Testosterone & $1.01 \pm 0.04(9)$ & $1.23 \pm 0.08(6)^{* *}$ & $1.33 \pm 0.06(8)$ & $1.01 \pm 0.11(7)$ \\
\hline
\end{tabular}

"Values are mean \pm standard error $(N)$.

** Significance compared to control (cocoa butter) by Student's $t$ test, $P<0.025$.

$* * * P<0.005$. 
TABLE 3

The Influence of Perivisceral Injection of a Variety of Steroids on Pituitary Gonadotropin (Gth) Content in Sexually immature Rainbow Trout

\begin{tabular}{llcc}
\multicolumn{1}{c}{ Treatment } & Pituitary GtH" & Significance \\
\hline Control (cocoa butter) & $N$ & $($ ng) & - \\
Testosterone (T) & 5 & $1.9 \pm 1.3$ & $P<0.01$ \\
Testosterone propionate & 6 & $185 \pm 35$ & $P<0.01$ \\
$17 \alpha$-Methyltestosterone & 6 & $134 \pm 34$ & $P<0.02$ \\
Androstenedione & 6 & $118: \pm 28$ & $P<0.01$ \\
$5 \alpha$-Dihydrotestosterone & 6 & $116 \pm 11$ & $\mathrm{NS}$ \\
11 -Ketotestosterone & 5 & $0.4 \pm 0.1$ & $\mathrm{NS}$ \\
$11 \beta$-Hydroxytestosterone & 5 & $1.2 \pm 0.4$ & $P<0.01$ \\
Estradiol-17 $\beta$ (E E $_{2}$ ) & 4 & $3.0 \pm 1.6$ & $P<0.01$ \\
Estrone & 6 & $171 \pm 18$ & $P<0.01$ \\
Estriol & 4 & $22.6 \pm 15.6$ & $\mathrm{NS}$ \\
$17 \alpha$-Hydroxyprogesterone & 6 & $33.2 \pm 6.3$ & $\mathrm{NS}$ \\
$17 \alpha$-Hydroxy-20 $\beta$-Dihydroprogesterone & 6 & $3.4 \pm 1.9$ & $\mathrm{NS}$ \\
Cholesterol & 6 & $1.4 \pm 0.7$ & \\
\hline
\end{tabular}

"Values are mean \pm standard error.

"Significance compared to control by $U$ test.

$17 \alpha$-hydroxyprogesterone and $17 \alpha, 20 \beta$-dihydroxyprogesterone, which have been identified in teleost plasma (Campbell et al., 1980), did not alter pituitary GtH levels. Once again as determined in experiment 1 , the low basal plasma GtH levels were unchanged at 7 days following the steroid injection (data not shown). These data indicate that only estrogen and aromatizable androgens are effective in causing the elevation of pituitary GtH.

Table 4 summarizes the effects of the aromatase inhibitor ATD on the pituitary
GtH response to $\mathrm{T}$ in experiment 2. ATD did not alter pituitary GtH when given alone, and the low dose of ATD did not alter the pituitary GtH response to T. However, the high dose of ATD significantly reduced the pituitary GtH response to $T$. This confirms that only aromatizable androgens are effective in causing the positive feedback effect on pituitary GtH.

In experiment 3 androgen hormones were administered to juvenile trout in a peanut oil injection vehicle. This was done to evaluate the previous information regarding

TABLE 4

The Influence of Perivisceral Injection of Aromatase Inhibitor (ATD) on the Pituitary Gonadotropin (Gth) Content Induced by Testosterone in Sexually immature Rainbow Trout

\begin{tabular}{|c|c|c|c|c|}
\hline Treatment & $N$ & $\begin{array}{c}\text { Pituitary GtH" } \\
\text { (ng) }\end{array}$ & $\begin{array}{c}\text { Significance }{ }^{\prime} \\
\text { (compared to control) }\end{array}$ & $\begin{array}{c}\text { Significance" } \\
\text { (compared to } \mathrm{T})\end{array}$ \\
\hline Control (cocoa butter) & 5 & $1.9 \pm 1.3$ & - & - \\
\hline Testosterone $(\mathrm{T})$ & 6 & $185 \pm 35$ & $P<0.01$ & - \\
\hline ATD $(20 \mu \mathrm{g})$ & 6 & $1.5 \pm 0.5$ & NS & - \\
\hline ATD $(100 \mu \mathrm{g})$ & 6 & $2.2 \pm 0.6$ & NS & - \\
\hline ATD $(20 \mu \mathrm{g})$ and T & 6 & $196 \pm 50$ & $P<0.01$ & NS \\
\hline ATD $(100 \mu \mathrm{g})$ and $T$ & 6 & $89.6 \pm 9.1$ & $P<0.01$ & $P<0.025$ \\
\hline
\end{tabular}

"Values are mean \pm standard error.

${ }^{b}$ Significance determined by $U$ test. 
TABLE 5

The Influence of Per!visceral Injection of Testosterone and other Androgens on Pituitary GtH Content in IMMATURE RAINBOW TROUT

\begin{tabular}{lccc}
\hline \multicolumn{1}{c}{ Treatment } & Pituitary GtH & \\
& $N$ & $(\mathrm{ng})$ & Significance $^{\prime \prime}$ \\
\hline Control (peanut oil) & 6 & $0.5 \pm 0.05$ & - \\
Testosterone & 6 & $66.3 \pm 5.6$ & $P<0.001$ \\
$5 \alpha$-Dihydrotestosterone & 6 & $0.4 \pm 0.03$ & $\mathrm{NS}$ \\
11 -Ketotestosterone & 6 & $2.1 \pm 0.6$ & $P<0.05$ \\
$11 \beta$-Hydroxytestosterone & 6 & $1.3 \pm 0.4$ & $P<0.01$ \\
\hline
\end{tabular}

"Values are mean \pm standard error.

${ }^{b}$ Significance compared to control by $U$ test.

the inability of dihydrotestosterone and the 11-oxygenated androgens in a cocoa butter vehicle to stimulate pituitary GtH. The results in Table 5 show that the low pituitary GtH levels in immature trout remain unaltered by dihydrotestosterone. A very small but significant $\mathrm{GtH}$ increase was induced by treatment with 11-ketotestosterone and $11 \beta$-hydroxytestosterone. Testosterone treatment in an oil vehicle increased pituitary GtH to significantly higher levels similar to the testosterone response observed in other experiments using injection of a cocoa butter vehicle.

\section{DISCUSSION}

In salmonids the pituitary GtH content is low in sexually immature and regressed fish, but it rises and reaches a peak at the time of spawning (Billard et al., 1978; Crim and Evans, 1978; Dodd et al., 1978; Billard and Breton, 1979). Administration of $\mathrm{T}$ to sexually immature (juvenile) rainbow trout induces a rapid accumulation of GtH in the pituitary (Crim and Evans, 1979). A previous study of the influence of testosterone implantation into the brain or pituitary gland of Atlantic salmon parr (Crim and Peter, 1978) demonstrated that the pituitary $\mathrm{GtH}$ response was similar in both males and females. Estradiol-17 $\beta$ injections into sexually immature silver eels induces differentiation of pituitary gonadotropic cells, which become heavily laden with deepstaining basophilic granules after long-term steroid treatment (Olivereau and Olivereau,
$1979 a, b)$. It is clear from the present work that both androgen and estrogen treatments of prepubertal trout are capable of quickly elevating GtH levels in the pituitary gland. The mechanism for this response is not known, but it is likely that it reflects the initiation or an acceleration of $\mathrm{GtH}$ production. It is unlikely that pituitary GtH secretion is blocked by steroid treatment causing an accumulation of $\mathrm{GtH}$ in the pituitary, because pituitary and plasma GtH levels of the immature trout are low and no changes in plasma GtH were detected. Furthermore, the gonadotrophs of immature salmonid fishes are either undifferentiated (Nagahama, 1973; Robertson and Wexler, 1962) or largely inactive (McKeown and Leatherland, 1973).

The present investigation demonstrated that accumulation of GtH in the trout pituitary was stimulated by estrogens including estrone, estradiol-17 $\beta\left(\mathrm{E}_{2}\right)$, and estriol, although $E_{2}$ was the most effective. Some of the androgens tested such as testosterone, $17 \alpha$-methyltestosterone and testosterone propionate stimulated pituitary $\mathrm{GtH}$ as expected. Pituitary GtH also increased after androstenedione injection, which would be expected from the position of this steroid along the androgen biosynthetic pathway reported for the teleost testes (Arai and Tamaoki, 1967). Androgens present in plasma of sexually mature teleosts include 11-oxygenated steroids, 11-ketotestosterone, and $11 \beta$-hydroxytestosterone (Ozon, 1972; Campbell et al., 1980). 11-Ketotes- 
tosterone and $11 \beta$-hydroxytestosterone are not aromatized to estrogen, apparently due to steric hindrance with the aromatase enzyme system (Engel, 1975). These two androgens were not effective in elevating pituitary GtH in experiment 2 , in which $20 \mu \mathrm{g}$ of steroid was given PV in cocoa butter; however, a higher dose produced a significant effect of small magnitude in experiment 3 when three injections of $20 \mu \mathrm{g}$ each in peanut oil were given on alternate days. Possibly the significant effects of 11ketotestosterone and $11 \beta$-hydroxytestosterone in experiment 3 were due to contamination of the preparations by aromatizable steroids or the very high doses used. $5 \alpha$-Dihydrotestosterone was another androgen found to be inactive for stimulating pituitary GtH accumulation in immature trout. Reduction of testosterone to $5 \alpha$-dihydrotestosterone is irreversible, so that aromatization of $5 \alpha$-dihydrotestosterone to estrogen is not possible (Engel, 1975). Cholesterol, and the C-21 sex steroids, $17 \alpha$-hydroxyprogesterone and $17 \alpha$ hydroxy-20 $\beta$-dihydroprogesterone, which are present in female fish plasma (Campbell et al., 1980), did not significantly alter pituitary GtH levels in the immature trout. Whereas metabolism of these steroids could occur in the liver or in steroidogenic tissues (e.g., conversion of $17 \alpha$-hydroxyprogesterone to androstenedione), the amount of such conversion products, if present, were insufficient to be effective at the hypothalamo-hypophysial level. These data taken together strongly suggest that the steroid action on elevation of pituitary $\mathrm{GtH}$ in immature fish is estrogen dependent, or with androgens which are active, the conversion into estrogen may be necessary. Since pituitary $\mathrm{GtH}$ is elevated by testosterone in Atlantic salmon parr (Crim and Peter, 1978), the action of these steroids on pituitary GtH levels in fish undergoing sexual maturation may also be of importance.

The importance of aromatase in $\mathrm{GtH}$ stimulation by androgen in the trout was tested by attempting to interfere with the aromatase enzyme system. Estrogen biosynthesis in placental microsome preparations is suppressed by $1,4,6$-androstatriene-3,17-dione (ATD), an aromatase inhibitor (Schwarzel et al., 1973) and this inhibitor reduced testosterone conversion into estrogen, in vivo, in female rats (Leiberberg et al., 1977). ATD suppressed the trout pituitary $\mathrm{GtH}$ response to testosterone in the present study; furthermore, we have established that 19-hydroxytestosterone, an aromatase substrate, also stimulates pituitary $\mathrm{GtH}$ in the immature rainbow trout (unpublished information).

$E_{2}$ treatment by $P V$ injection with a cocoa butter carrier was effective in stimulation of HSI in male and female immature trout in experiment 1 . In addition, $\mathbf{T}$ and cortisol treatment by PV injection stimulated HSI of the female trout. However, pituitary implantation of these steroids did not increase the HSI. Since $\mathrm{T}$ and $\mathrm{E}_{2}$ were effective in causing increased pituitary GtH equally well in males and females when given by PV injection or pituitary implantation, it is clear that increase in pituitary $\mathrm{GtH}$ occurs as a result of central effects of the steroids.

The mechanism of steroid feedback regulation of fish reproductive cycles is thought to involve uptake and binding of steroid hormones in the brain and pituitary. Testosterone uptake into the rainbow trout brain and pituitary gland was demonstrated by Schreck (1973). Sex steroid hormone localization into specific teleost brain centers and the teleost pituitary gland (Davis et al., 1977; Kim et al., 1978) is of interest because some of these hypothalamic areas are potent sites of steroid transformation. Aromatase has been localized in the hypothalamus, the preoptic area, and some telencephalic structures of the lower vertebrates (Callard et al., 1978). In higher animals, homologous brain areas also contain aromatase activity and these centers serve to control gonadotropic hormone secretion, sex behavior, and reproductive cycles.

In sexually mature salmonids there are 
high levels of sex steroids present in the plasma (Idler et al., 1971; Billard et al., 1978; Dodd et al., 1978; Campbell et al., 1980 ), and a clear negative feedback effect of androgen on the hypothalamohypophysial axis has been demonstrated (Billard et al., 1977; Billard, 1978). This study indicates that aromatizable androgens and estrogens can have a positive feedback effect on the pituitary of sexually immature rainbow trout to cause an accumulation of GtH in the pituitary. Although androgen levels are relatively low in salmonids at the time of onset of gonadal recrudescence (Dodd et al., 1978; Billard et al., 1978), a small peak in plasma $E_{2}$ has been described at about the time of onset of gonadal recrudescence in rainbow trout and brown trout (Billard et al., 1978). Whether endogenous $E_{2}$ or other steroids from the gonads of immature salmonids has a positive feedback effect on the hypothalamohypophysial axis to stimulate accumulation of GtH in the pituitary, and perhaps also trigger GtH secretion to initiate the onset of gonadal recrudescence, is not known.

\section{ACKNOWLEDGMENTS}

This research was supported by NATO Grant 1305 , and Grants A-9729 to L.W.C. and A-6371 to R.E.P. from the Natural Sciences and Engineering Research Council of Canada. Travel to France by R.E.P. and travel to Canada by R.B. was supported by NRC Canada-CNRS France Exchange Scientist grants.

\section{REFERENCES}

Arai, R., and Tamaoki, B. (1967). Steroid biosynthesis in vitro by testes of rainbow trout, Salmo gairdneri. Gen. Comp. Endocrinol. 8, 305-313.

Billard, R. (1978). Testicular feedback on the hypothalamo-pituitary axis in rainbow trout (Salmo gairdneri R.). Ann. Biol. Anim. Biochim. Biophys. 18, 813-818.

Billard, R., and Breton, B. (1979). Rhythms of reproduction in teleost fish. In "Rhythmic Activity in Fish" (J.E. Thorpe, ed.), pp. 31-53. Academic Press, New York.

Billard, R., Breton, B., Fostier, A., Jalabert, B., and Weil, C. (1978). Endocrine control of the teleost reproductive cycle and its relation to external factors: Salmonid and cyprinid models. In "Comparative Endocrinology" (P. J. Gaillard and H. H
Boer, eds.), pp. 37-48. Elsevier/North-Holland, Amsterdam.

Billard, R., and Peter, R. E. (1977). Gonadotropin release after implantation of anti-estrogens in the pituitary and hypothalamus of goldfish, Carassius auratus. Gen. Comp. Endocrinol. 32, 213-221.

Billard, R., Richard, M., and Breton, B. (1977). Stimulation of gonadotropin secretion after castration in rainbow trout. Gen. Comp. Endocrinol. 33, 163-165.

Callard, G. V., Petro, Z., and Ryan, K. J. (1978). Conversion of androgen to estrogen and other steroids in the vertebrate brain. Amer. Zool. 18, $511-523$.

Campbell, C. M., Fostier, A., Jalabert, B., and Truscott, B. (1980). Identification and quantification of steroids in the serum of rainbow trout during spermiation and oocyte maturation. J. Endocrinol. 85, 371-378.

Crim, L. W., and Evans, D. M. (1978). Seasonal levels of pituitary and plasma gonadotropin in male and female Atlantic salmon parr. Canad. J. Zool. 56, $1550-1555$.

Crim, L. W., and Evans, D. M. (1979). Stimulation of pituitary gonadotropin by testosterone in juvenile rainbow trout (Salmo gairdneri). Gen. Comp. Endocrinol. 37, 192-196.

Crim, L. W., and Peter, R. E. (1978). The influence of testosterone implantation in the brain and pituitary on pituitary gonadotropin levels in Atlantic salmon parr. Ann. Biol. Anim. Biochim. Biophys. $18,689-694$.

Crim, L. W., Watts, E. G., and Evans, D. M. (1975). The plasma gonadotropin profile during sexual maturation in a variety of salmonid fishes. Gen. Comp. Endocrinol. 27, 62-70.

Davis, R. E., Morrell, J. I., and Pfaff, D. W. (1977). Autoradiographic localization of sex steroidconcentrating cells in the brain of the teleost $\mathrm{MaC}$ ropodus opercularis (Osteichthyes:Belontiidae). Gen. Comp. Endocrinol. 33, 496-505.

Dodd, J. M., Stuart-Kregor, P. A. C., Sumpter, J. P., Crim, L. W., and Peter, R. E. (1978). Premature sexual maturation in the Atlantic salmon (Salmo salar L.). In "Comparative Endocrinology" (P. J. Gaillard and H. H. Boer, eds.), pp. 101-104. Elsevier/North-Holland, Amsterdam.

Ekengren, B., Peute, J., and Fridberg, G. (1978). Gonadotropic cells in the Atlantic salmon, Salmo salar. An experimental immunocytological, electron microscopical study. Cell Tissue Res. 191, $187-203$.

Engel, L. L. (1975). The biosynthesis of estrogens. In "Handbook of Physiology" (R. O. Greep, ed.), Sect. 7, Vol. 2, Part 1, pp. 467-484. Amer. Physiol. Soc. Washington, D.C.

Idler, D. R., Horne, D. A., and Sangalang, G. B. (1971). Identification and quantification of the 
major androgens in testicular and peripheral plasma of Atlantic salmon (Salmo salar) during sexual maturation. Gen. Comp. Endocrinol. 16, 257-267.

Kim, Y. S., Stumpf, W. E., Sar, M., and MartinezVargas, M. C. (1978). Estrogen and androgen target cells in the brain of fishes, reptiles and birds: Phylogeny and ontogeny. Amer. Zool. 18, 425-433.

Lieberburg, I., Wallach, G., and McEwen, B. S. (1977). The effects of an inhibitor of aromatization (1,4;6-androstatriene-3,17-dione) and an antiestrogen (CI-628) on in vivo formed testosterone metabolites recovered from neonatal rat brain tissues and purified cell nuclei. Implications for sexual differentiation of the rat brain. Brain Res. 128, $176-181$

McKeown, B. A., and Leatherland, J. F. (1973). Fine structure of the adenohypophysis in immature sockeye salmon, Oncorhynchus nerka. $Z$. Zellforsch. Mikrosk. Anat. 140, 459-471.

Nagahama, Y. (1973). Histo-Physiological studies on the pituitary gland of some teleost fishes, with special reference to the classification of hormone-producing cells in the adenohypophysis. Mem. Fac. Fish. Hokkaido Univ. 21, 1-63.

Olivcreau, M. (1976). Les cellules gonadotropes hypophysaires du Saumon de l'Atlantique: Unicité ou dualité? Gen. Comp. Endocrinol. 28, 82-95.

Olivereau, M., and Olivereau, J. (1979a). Effect of Estradiol-17 $\beta$ on the cytology of the liver, gonads and pituitary, and on plasma electrolytes in the female freshwater eel. Cell Tissue. Res. 199, $431-454$

Olivereau, M., and Olivereau, J. (1979b). Estradiolpositive feedback on gonadotropic $(\mathrm{GtH})$ cells in freshwater male silver eels. Gen. Comp. Endocrinol. 39, 247-261.

Ozon, R. (1972). Androgens in fishes, amphibians, reptiles, and birds. In "Steroids in Nonmammalian Vertebrates"' (D. R. Idler, ed.), pp. 329-385. Academic Press, New York.

Peute, J., Goos, H. J. Th., DeBruyn, M. G. A., and Van Oordt, P. G. W. J. (1978). Gonadotropic cells of the rainbow trout pituitary during the annual cycle. Ultrastructure and hormone content. Ann. Biol. Anim. Biochim. Biophys. 18, 905-910.

Robertson, O. H., and Wexler, B. C. (1962). Histological changes in the pituitary gland of the rainbow trout (Salmo gairdneri) accompanying sexual maturation and spawning. J. Morphol. 110, 157- 170 .

Schreck, C. B. (1973). Uptake of ${ }^{3} \mathrm{H}-\mathrm{Testosterone}$ and influence of an anti-androgen in tissues of rainbow trout (Salmo gairdneri). Gen. Comp. Endocrinol. 21, 60-68.

Schwarzel, W. C., Kruggel, W. G., and Brodie, H. J. (1973). Studies on the mechanism of estrogen biosynthesis. VIII. The development of inhibitors of the enzyme system in human placenta. Endocrinology 92, 866-880.

Sokal, R. R., and Rohlf, F. J. (1969). "Biometry.", Freeman, San Francisco.

Sundararaj, B. I., and Goswami, S. V. (1968). Effects of estrogen, progesterone and testosterone on the pituitary and ovary of catfish, Heteropneustes fossilis (Bloch). J. Exp. Zool. 169, 211-228.

Viswanathan, N., and Sundararaj, B. I. (1974). Response of the hypothalamohypophysial-ovarian system of the catfish, Heteropneustes fossilis (Bloch), to administration of estrogen and androgen. Neuroendocrinology 16, 212-224. 